THE CANADIAN JOURNAL OF AUTISM EQUITY LA REVUE CANADIENNE DE L'ÉQUITÉ EN MATIÈRE D'AUTISME \begin{tabular}{l|l|l} 
VOLUME 1 & ISSUE 1 & APRIL 2021
\end{tabular}

\title{
Intersectionality, The Social Model of Disability, and Identity
}

Amy Kim, University of Victoria, Canada 


\title{
Intersectionality, The Social Model of Disability, and Identity
}

\author{
Amy Kim ${ }^{1}$ (D)
}

\begin{abstract}
The introductory graphic represents the identity conflict that the author experiences daily. The terms represent labels assigned to the author in the past, the barriers that Autistic people must constantly overcome, and some of the social rules the author has very consciously and intentionally adopted to "fit in" with society. The accompanying experience piece outlines some of the difficulties the author has experienced that suggest that there needs to be more awareness in Canadian society regarding autism and intersectionality. Anecdotally, there appears to be a need for increased access to diagnostic and clinical services across Canada for women across the spectrum, and further investigation into how disability, race, and gender interact.

Résumé
\end{abstract}

Le graphique d'introduction représente le conflit d'identité que l'auteure vit au quotidien. Ses termes représentent les étiquettes qui lui ont été attribuées dans le passé, les obstacles que les personnes autistes doivent constamment surmonter et certaines des règles sociales que l'auteure a très

consciemment et intentionnellement adoptées pour «s'intégrer »à la société. L'article qui accompagne le graphique décrit certaines des difficultés que l'auteure a rencontrées et qui suggèrent que la société canadienne doit être davantage sensibilisée à l'autisme et à l'intersectionnalité. De façon anecdotique, il semble qu'il faille améliorer l'accès aux services diagnostiques et cliniques de part et d'autre du Canada pour les femmes sur le spectre de l'autisme, et approfondir les recherches sur l'interaction entre le handicap, la race et le sexe.

Keywords

Autism, Intersectionality, Disability, Identity, Equity Mots clés Autisme, Intersectionnalité, Handicap, Identité, Équité

\footnotetext{
1 University of Victoria, Canada
} 


\section{SAE NARCISSISTIC D I V E R S I T Y \\ O B S SE S S \\ ISOLATION \\ A NTISOCHA LMAKE \\ UNDERSTAND HOW \\ $A N \times+O=S^{\circ}$ \\ E ATING DISORDER}

D I S CRI M I N A TIO N C O L D D THINGS FOR EACH OTHER .

CONTROL F REAK

BORDERLINEAVOID MELTDO

I A M A U T I S T I C

O 5 Tी

$P O O R$ TEAM PLAYER

STUCK. UP EYE CONTACT

- WE KEEP YOU AROUND.CR A Z YSECONDS

BE S N S ORY O V F R L O A D

MINORITY DEPRESSED

REASONABLEACCOMODATIO.N $A L O \bigcirc F$ B U L L I N G

R A C I S M A D H D

H A R A S S M E N T 
As an Autistic woman and as a first-generation immigrant, the barriers I have faced during my lifetime have felt at times to be insurmountable. Diagnosed relatively late at 27 , the revelation that there was a reason for why my life had been so chaotic and confusing was in some way a relief. However, at a major turning point in my life, this revelation also led me to the uncomfortable realization that I lived a life devoid of authenticity, which resulted in what can only be described as an extreme conflict in identity. The regret, anger, and sadness that I felt at the realization that I had spent the last couple of decades "trying to be good" and trying to conform to the expectations of other people resonates strongly with the experience of many other Autistic women, pointing to the stark reality of gender-based inequity in current clinical practice (Bargiela et al., 2016, p. 3286). The interconnectedness between ethnicity, gender, and disability in my narrative also underscores the need for autism research concerning historically marginalized groups.

From a very young age, I always felt very different from my peers. One of my earliest and enduring memories is of a classmate who I thought was my friend giving every girl in my class a Christmas present except for me, stating to a peer that I made her feel "uncomfortable". And the idea that there was something inherently and seriously wrong with me only grew as I grew. To avoid the chronic bullying I endured during my childhood, I began to "pretend to be normal", as many Autistic women report doing at some point in their lifetimes (Bargiela et al., 2016). But despite my best and most earnest attempts, I found that being negatively labelled was unavoidable.

Even though I generally tried to avoid confrontation and stay out of the way, I found that black-and-white thinking made this nearly impossible and would only result in me being seen as stuck-up, aloof, and labelled as an "antisocial bitch". If I tried to contribute to the group, then I was an insufferable know-it-all. Despite graduating as valedictorian of my high school, after disclosure, I would be assigned to alphabetizing files. Female colleagues would make off-hand and thinly veiled comments about my eating habits, making sure to whisper the words "eating disorder" within earshot. Employers would label me as bipolar following multiple misunderstandings and meltdowns. And because I collected clothing and makeup instead of stamps, trains, or buttons, I would be reduced to being vain and superficial despite my work ethic. From being asked if I am running a massage parlour at an IT job to being told I cannot possibly recognize harassment and discrimination because I am Autistic, I can say that my interactions with others have ranged from mildly irritating and confusing to truly incredulous.

There is no instruction manual for how to conduct yourself in these kinds of situations. Current conceptualizations of autism in clinical practice ignore empirical evidence that Autistic women show a higher social motivation to "fit in" than Autistic men and that females require more severe symptoms and greater cognitive and behavioural problems in order to be diagnosed (Bargiela et al., 2016; Mandy et al., 2012). Arguably, this gender bias, which can prevent the identification of needs and appropriate interventions and services, becomes even more 
complicated when gendered racial stereotypes and the "model minority" myth are taken into account.

Within a pan-ethnic category of "Asian", the expectation of passivity and submissiveness commonly associated with the model minority myth is further popularized by the pervasiveness of problematic portrayals of Asian women in popular media (Cho, 1997; Lee, 2015). Perpetually caught between the stereotypes of being the meek, subservient, and overly-sexualized "Lotus Blossom", and the untrustworthy, foreign and conniving "Dragon Lady", the complex set of power dynamics culminating from this convergence of racial and gender stereotypes results in a social landscape that is, needless to say, extremely confusing for an autistic person to traverse. With characterizations ranging from the "tragically passive" to "demonically aggressive", I was simultaneously expected to be invisible, yet part of the group. I resigned myself to a "damned if you do, damned if you don't" mentality, which resulted in many years of unhappiness and a profound loss of self (Cho, 1997, p.185).

My recent involvement with the Canadian Journal of Autism Equity and the Canadian Autism Spectrum Disorder Alliance, and my introduction to the Social Model of Disability, has allowed me to shift my focus from "what's wrong with me?" to "how can we improve the quality of life of Autistic Canadians and make sure their voices are heard?" (Shakespeare, 2006). In alignment with the Canadian Autism Spectrum Disorder Alliance's goal of implementing a National Autism Strategy in Canada, this last question is one we should all be seriously asking ourselves. A paradigm shift is long overdue. As a society, we are more than capable of moving beyond moral grandstanding and flaunting "diversity" and "multiculturalism" to ensuring equality of opportunity for all Canadians, regardless of disability, race, or gender. And as for the question of, "who am I?" I am now proudly able to say that I am no one but me. And I am Autistic.

\section{ORCID iD}

Amy Kim (iD) https://orcid.org/0000-0001-9425-4981

\section{References}

Bargiela, S., Steward, R., \& Mandy, W. (2016). The experiences of late-diagnosed women with autism spectrum conditions: An investigation of the female autism phenotype. Journal of Autism and Developmental Disorders, 46(10), 3281-3294. https://doi.org/10.1007/s10803-016-2872-8

Cho, S. K. (1997). Converging stereotypes in racialized sexual harassment: Where the model minority meets Suzie Wong. Journal of Gender, Race \& Justice, 1, 177-212. https://via.library.depaul.edu/ lawfacpubs/710/

Lee, S. J. (2015). Unraveling the" model minority" stereotype: Listening to Asian American youth (2nd ed.). Teachers College Press.

Shakespeare, T. (2006). The social model of disability. In L. J. Davis (Ed.), The Disability Studies Reader (5th ed., pp 197-204). Taylor \& Francis.

Mandy, W., Chilvers, R., Chowdhury, U., Salter, G., Seigal, A., \& Skuse, D. (2012). Sex differences in autism spectrum disorder: Evidence from a large sample of children and adolescents. Journal of Autism and Developmental Disorders, 42, 1304-1313. https://doi.org/10.1007/s10803-011-1356-0 